\title{
The Concept of Dravya in Yogācāra and Vaiśeșika: a Comparative Philosophical Analysis
}

Abstract: The concept of dravya is used both in Buddhism and Brāhmanical systems of philosophy, but its meanings there are quite different. According to Vaiśeșika as one of the Brāhmanical systems dravya is a real substance independent of any knowing subject and reality is constituted by relations between substances. In Yogācāra Buddhism, on the opposite, substances are regarded as mere designations existing only in dependence of a knowing subject. Any entity may be treated as a substance or a mere conceptualization depending on a concrete situation with the perspective of nirvāna.

Key words: the concept of substance, Abhidharma, Asanga, Praśastapāda.

The concept of dravya is often referred to in philosophical and religious texts of such a different intellectual traditions of India as the Brāhmanical systems of Vedānta, Sāmkhya and especially Vaiśeșika on the one hand and Buddhism or Jainism on the other. But the exact meaning of the term dravya, usually translated as "substance", is a subject of considerable discussions concerning its genesis, connotations and transformations in the run of the history of a system. Even the translation of dravya as "substance" is quite arguable, for substance e definitione means some entity immutable in itself, whereas dravya is not necessarily characterized by immutability.

We will not try to cover the whole scope of problems associated with the interpretation of this term in Indian philosophy, as well as the whole scope of philosophical systems of ancient and medieval India in this brief paper, and restrict the subject of our study to only two systems, namely Vaiśeșika and Yogācāra Buddhism as presented in Praśastapāda's "Compendium of the characteristics of categories" (Padārtha-dharma-samgraha) with Śrīdhara's commentary "Blooming tree of the method" (Nyāya-kandalī), and the

(C) Sergey L. Burmistrov, D. Sci. (Philosophy), Leading Researcher of the Department of the Central and South Asia, Institute of Oriental Manuscripts, RAS (s.burmistrov@, hotmail.com) 
"Compendium of Abhidharma" (Abhidharma-samuccaya) by Asanga respectively. These schools and texts were chosen mainly because of the significance of Praśastapāda's work in the history of philosophy in India, for it is in Vaiśeșika that the notion of dravya is used as a basic term of the system. Asanga (and, wider, Yogācāra as a system) presents, as is usually (and not correctly) considered, strictly idealistic philosophy with the concept of vijñana (consciousness) as a fundamental principle explaining the existence of both mind and "material" world - or, more exactly, mind enlightened and free from affects (Skt. kleśa, Pāli kilesa) and the notion of eternal and changeless soul or "I", and mind unenlightened, affected by kleśas and addicted to the idea of "I" that forms the basis of samsāra. The concept of substance (dravya) in this context is peculiarly interesting in that it can highlight a characteristic feature of Buddhist philosophical thought that can be called the substantiality of mind. This means that Buddhists, despite of their commonly accepted pluralism or even "psychological atomism" with the idea of multiple dharmas that the whole reality is composed of, did not consider these as material entities as e.g. Jainas did, but rather as facts of mind, for even the material world (in common-sense meaning of the word) was thought of as a result of karmic activities of a sentient being that suffers from (or enjoys) consequences of his former deeds. This can be seen even in nidānas of pratîtya-samutpāda where consciousness (Skt. vijñāna) goes before the material form (Skt. nāmarūpa) of a being.

Before proceeding to the investigation into the meaning of the term dravya in philosophical texts it would be useful to explicate briefly how this term is used in Indian epics. In Mahābhärata it denotes almost solely some material substance like something that can be offered in a sacrifice or used in a daily human activities. Thus in Bhișmaparvan we read: "Some offer a material substance in a sacrifice, some a religious ardour, some yoga" (dravyayajñās tapoyajñā yogayajñās tathāpare). ${ }^{1}$ But "sacrifice by the absolute knowledge is better than a sacrifice with material substances" (śreyān dravyamayād yajñāj jñānayajñah paramtapa). ${ }^{2}$ In Dronaparvan Bhișma orders to bring him his chariot horsed with the best horses and ornamented with pearls that shine like the sun and the moon and furnished with all the accessories (dravya) necessary for battle (ratnaiś citram candrasüryaprakaśaị dravyair yuktam samprahāropapannair; Droṇaparvan, 2, verse 27). ${ }^{3}$ Further, in chap-

\footnotetext{
${ }^{1}$ Bhișmaparvan 26, verse 28.

${ }^{2}$ Bhișmaparvan 26, verse 33 .

${ }^{3}$ Dronaparvan 1958, 16.
} 
ter 119, Sañjaya tells about the tribe of Vṛșni saying that they are righteous and do not encroach on the properties (dravya) of brāhmanas, teachers and relatives (brahmadravye gurudravye jñätidravye 'py ahimsakāh; Droṇaparvan, 119 , verse 24). ${ }^{4}$ Describing Dāruna's chariot he tells that it was supplied with all the accessories (dravya) of king's chariot. In Śalyaparvan (35, verse 2) Halāyudha, having arrived to Udapāna, distributes a lot of riches (dravya) among people there. ${ }^{5}$ The same usage is common in other parts of the epic as well, so it is clear enough from the above that in epic Sanskrit texts dravya denoted something commonly material - property, wealth, accessories for some activity (ritual, martial etc.) or, putting it simple, something that can be taken by hand or possessed by somebody.

Turning now to philosophical traditions of ancient India, we see that the term takes there a more abstract meaning that comprises now not only strictly material things but also such notions as time, space, attman etc. In Jaina texts, for example, this term is referred to in different contexts that demonstrate that dravya in Jaina philosophy can not be interpreted as "substance" exactly, for substance in modern European philosophy means a reale that is not subject to any changes induced by external causes, while in Jainism change is not only possible for dravya but, what is more, in some cases is necessarily a subject to principal modifications caused from without. The scope of meanings of the concept embraces not only substance as an eternal basis of all the objects in the world, not created by a god or some other supernatural power, but includes also a substratum for attributes (guna) and moduses (paryaya $\overline{)}$, and, moreover, a concrete thing an empirical object of this phenomenal world, so that it can be a synonym to artha and vișaya. ${ }^{6}$ Thus, according to Umāsvāti's Tattvārtha-adhigama-sūtra the list of dravyas includes condition for movement, condition for rest, space, matter and souls (TS 5.1-3: aj̄̄vakāyā dharmādharmākāśa pudgalah, dravyānị; jūvāśca), all these being eternal, immutable in itself and formless (except matter): nityāvasthi tānyarūpāni; rüpinah pudgalah (TS 5.4-5). ${ }^{7}$ At first sight this contradicts to our thesis that dravya in Jaina philosophy is subject to changes, but this contradiction is only seeming, for in fact two of these substances, namely matter (pudgala) and soul (jīva) are active and not unitary (TS 5.6-7: $\bar{a}$ ākāśädekadravyāni niṣkriyāṇi ca) ${ }^{8}{ }^{8}$ This means that these can undergo

\footnotetext{
${ }^{4}$ Dronaparvan 1958, 668.

${ }^{5}$ Śalyaparvan 1961, 261.

${ }^{6}$ ZHELEZNOVA 2012, 403.

${ }^{7}$ Ibidem, 132-133.

${ }^{8}$ Ibidem.
} 
changes, for it is these that produce movement and karmic matter. In Pūjyapāda's Sarvārthasiddhi (a latter commentary on TS) we read that "substance is that which undergo (dravyante) modifications (paryaya)", and in TS itself: "substance [is that which has] attributes and modi" (TS 5.38: gunaparyayavadravyam). ${ }^{9}$

Later Jaina authors draw a picture that could seem different from the basic views of the classical Jaina philosophy but in fact is nothing more than a result of evolution of cardinal ideas of the system. Kundakunda, a 3rd-4th cc. Jaina thinker, in his Samayasāra considers the problem of interaction between two dravyas, soul and karmic matter. ${ }^{10}$ But before we proceed to explicate Kundakunda's conception of interaction between these dravyas, it will be useful to make some notions concerning the term "substance" as it is understood in modern European philosophy. First of all, substance, as noted above, is immutable in itself, otherwise it would change its nature and could not be substance at all. Changes can only affect its attributes, as we can see, for instance, in the philosophical systems of Descartes and Spinoza. But the second characteristic feature of the concept following from the first one is that substances cannot interact, for any interaction would affect a substance and cause it to change its essence. This problem was topical for Descartes who invented the "theory of two clocks" to explain away the difficulty consisted in the fact that the two Cartesian substances (res cogitans and res extensa) are so exactly harmonized with each other that any event in the first one seems to be the cause for some event in the second one. Of course, if they would interact they would affect or condition each other and would not be two different entities but rather a unitary, single substance having matter and thought as its two attributes. This last way was followed by Spinoza who postulated the existence of only one absolute Substance equal to God with infinite number of attributes among which only matter and thought are cognizable for human mind. This solution removed the difficulty of harmonizing two (or more) independent substances with their activities caused solely by internal processes of a substance. Cartesian substances are, so to say, two causally disjoint spaces, each with its own causality determining processes only in itself, while in Spinoza's system we see only one causal space, so that one attribute can directly affect another one.

Returning to Jaina philosophy, we see that above considerations are only restrictedly applicable to the Jaina concept of dravya. In Samayasāra

\footnotetext{
${ }^{9}$ Ibidem, 141.

${ }^{10}$ Ibidem, 195-196.
} 
Kundakunda presents two different solutions for the problem of interaction of two dravyas (soul and matter). The first one consists in that the afflux of karmic matter causes ignorance that produces worldly states of consciousness and these, in their turn, provoke a new afflux of karmic matter ad infinitum. ${ }^{11}$ According to the second one, soul is never involved in the process of rebirth so the last appears to be illusory; in this theory samsāra is an illusion like in Advaita Vedānta. ${ }^{12}$ This peculiar theory may be the result of influence of some Brāhmanical systems of thought. It was hardly Vedānta that influenced the Jaina philosophy so much, for in the times of Kundakunda Vedānta made just first steps as a philosophical system in the strict sense of the word: Bādarāyana's works, as is well known, were written as late as in 1st-2nd cc. A.D. Yet some influence of a system or, more exactly, a trend of thought that had not yet been expressed in philosophical treatises or sütras and was passed only orally, cannot be excluded.

Some terms can be understood better when explained from the point of their etymology, and dravya is not an exclusion. Etymologically dravya is a derivative from the word $d r u$ that may mean "wood or any wooden implement; a tree or branch" and in the same time "running, going, motion". As a verb it means "to run, hasten, flee; to run up to, attack, assault; to become fluid, dissolve, melt" or "to hurt, injure, repent" ${ }^{13}$ So its etymology itself is in a sense dual, for the word may mean both a hard and stable thing and a fluid, a torrent, a run of a water stream. As a noun dravya means not only philosophical substance but also a thing, an object, the ingredients or materials of something, individual, object of possession, wealth, goods, money. ${ }^{14}$ So the term cannot be considered as an exact equivalent to the term substantia used in the Western philosophy. This is apparent even from the analysis of the usage of the term in the Jaina philosophy. This term, generally speaking, designates some entity that may change in itself but cannot change into something other, being always of the same nature. So the problem remains as to how one substance can bring any effect to another.

This notion is widely used not only in Jainism. We see it, for instance, in some Śaiva scriptures where it means a matter quite similar to that used in Jaina texts. In some Śaiva sects the idea of an innate impurity (mala) is accepted. This impurity, treated as a matter substance, produces ignorance dividing soul from God and making the soul turn in the wheel of death and

\footnotetext{
${ }^{11}$ Ibidem, 195.

12 Ibidem, 196.

${ }^{13}$ MONIER-Williams 1899, 502.

${ }^{14}$ Ibidem, 501.
} 
rebirth. Ignorance, being the effect of a material substance, can be removed solely by action (vyāparra), but the only action capable of removing mala is initiation ritual followed by rituals prescribed in the Śaiva scriptures. ${ }^{15}$ Turning back to the Jaina philosophy we see that there is an opposition of "substance" (dravya) and modification (paryaya) consisting in that "paryaya is what is called process, the becoming, the fleeting or the ever-changing phases of reality, while dravya is the thing or the being, the reality which is in the process of fleeting. And the two, the Jainas argue are inextricably mixed together, such that it does not make any sense to describe something as exclusively 'permanent', a dravya, without necessarily implying the presence of the opposite, the process, the fleetingness, the impermanence, the paryaya". ${ }^{16}$ So, applying this to above-mentioned systems of Śaivism, we can say that defiling matter that, according to this philosophy, forms a karma for each sentient being cannot change its nature essentially and all the transformations possible for this substance are just the modifications on external level but not alterations in its essence. Changes can touch, so to say, only the appearance of an essence but not the essence itself.

Other Saivite sects, such as Kāpālikas and Kālamukhas, are reported to use substances (dravya) for attaining liberation, these substances being not just material in abstract sense - pañcamakāra or meat (māmsa), wine (madhu), fish (matsya), grain (mudrā) and sexual intercourse (maithuna). Adepts of these sects tried to achieve the highest goal of these religious practices by eating meat and drinking wine, for, according to Kāpālika doctrine, absolute knowledge (bodha) of Śiva and communion with him are produced by consumption of these substances. ${ }^{17}$ Lorenzen observes that "In Tantric practices the partaking of wine and meat has both a hedonistic and eucharistic aspect but is in no way connected with materialism. Hedonistically, the first four of the five Ma-sounds - wine, meat, fish, and grain $(m u d r \bar{a})$ - are regarded as aphrodisiacs (uttejaka) preparatives for final maithuna or sexual union between the initiated adept and his female partner. [...] The eucharistic significance of the four preliminary ingredients is variously explained in tantric sources. ${ }^{18}$ Wine may be treated as Śakti, the meat as Siva, and the enjoyer as Bhairava himself, as is explained in Kulārnava-tantra ${ }^{19}$, and bliss sprung in the sexual union between the adept

\footnotetext{
${ }^{15}$ ACHARYA 2014, 10. SANDERSON 1992, 285.

${ }^{16}$ Matilal 1998, 130.

${ }^{17}$ LORENZEN 1991, 89.

${ }^{18}$ Ibidem 89.

${ }^{19}$ Ibidem 79-80.
} 
(representing Bhairava) and his female partner (representing Śakti) is mokșa. It should be noted, however, that not all these Śaivite substances were material in the most narrow sense, as a matter, a liquid or something edible or tangible in any way, and sexual communion, though material, was nevertheless not substance in European sense of the word, but rather action.

$* * *$

Vaiśeșika was one of the most elaborated philosophical systems of India and had many texts that explicated its basic notions. One of the most fundamental texts of the system is Praśastapāda's Padārtha-dharmasamgraha ("Compenduim of the Characteristics of Categories") with Śrīdhāra's commentary Nyāya-kandal̄ ("A Flowered Tree of Method"). Dravya in Vaiśeșika is one of the six basic categories (padārtha) summarized by Praśastapāda, the other categories being quality (guṇa), motion (karma), the general (sāmānya), the particular (viśeșa) and inherence (samavaya) (PDS 2). ${ }^{20}$ Their knowledge is considered to be the way to final beatitude as the ultimate goal of all the religious practices of Hinduism (dravyagunasāmānyaviśeșasamavāyānām șaṇnam padārthānām sādharmyavaidharmyatattvajñānam nihśreyasahetuh). However, this goal is common for most Indian philosophical treatises, though it is not necessarily called nihśrreyasa: e.g., it is mokșa in Vedānta, nirvāna or bodhi in Buddhism. The knowledge of the absolute truth is referred to as the way to final liberation and the ultimate goal of all religious practices, and this implies that the highest goal has an epistemological character as well as emotional or existential one.

Praśastapāda, enumerating the categories of the system, mentions dravya first, and Srīdhāra explains this referring to dravya as the basis or the substratum of all other categories. ${ }^{21}$ These Vaiśeșika authors adhere to the idea of strict difference between substance and its qualities. Unlike Buddhists, Vaiśeșikas suppose that there is no quality without substratum and there is no substratum that had no qualities, thought these may not be always cognizable for the mind that is unenlightened in the specific Brāhmanic sense. So dravya means here a reale that can have a quality or qualities, be in a relation to other dravyas (to be the same as some other dravya, to be of a common nature with it or to differ from it, to be inherent to something other, to move relative to something other, take a place relative to something other). Hence dravya is characterized here by 1) its qualities

\footnotetext{
${ }^{20}$ PraŚASTAPĀDA and ŚRĪDHĀra 1895, 6. See also: PraŚASTAPĀDA 2005, 31.

${ }^{21}$ PraŚAstapĀDA and ŚRīDHĀra 1895, 6-7. PraśastaPĀDA 2005, 31-32.
} 
and 2) its relations, and the essence of any concrete dravya is manifested in its characteristics and modes of movement.

In PDS Praśastapāda enumerates the following substances: earth, water, fire, wind, ākāśa, time, direction, àtman, internal organ (tatra dravyāṇi prthivaptejovāyvākāśakāladigātmamanāmsi), ${ }^{22}$ every substance being characterized by its specific qualities inherent only to one dravya or to several dravyas. For instance, the substance of earth has the characteristics of color, taste, odor, temperature, number, size, separateness, conjunction, disjunction, remoteness, nearness, heaviness, fluidity and elasticity (PDS 1.1: rüparasagandhasparśasaṃhyāparimānaprthaktvasamyogavibhāgaparatvāparatvagurutvadravatvasamskāra). ${ }^{23}$ Some of these characteristics are common for earth and other substances, some are peculiar only for this substance, so we see here all the Vaiśeșika categories: some gunas are characterized by sāmānya, being common for more than one dravya, and some other are characterized by viśeșa being unique for one dravya only. This treatise evidently demonstrates the dualistic metaphysics of Vaiśeșika: the basis of the world in this system is the set of dravyas and they stand in some relations to each other, have qualities and perform some activity, so the universe in this philosophy is presented as a set of substances and relations between them. This is well-known "atomism" of Vaiśeșika that became a peculiar feature of the system.

One of the most obvious traits of all these notions is that all their qualities, motion and relations are objects of human knowledge. In other words, a dravya is an entity that can be perceived immediately, if it is a material substance, or can be known by the mind, as concerns such substances as $\bar{a} k \bar{a} s a$, manas or âtman, holding in mind that $\bar{a} k \bar{a} s \dot{a} a$ is not a physical space but rather an epistemological horizon or the sphere of objects available to our knowledge. First of all it can be seen here that Vaiśeșika universe itself is a set of entities constituted by relations between them. Atman is a knowing subject given a set of objects that are to be known, but both these objects and this subject are substances (dravya) and the relation between them, that appears in an epistemological act, can be considered a root from which all phenomenal universe comes forth.

Here two levels of reality must be carefully discerned. The first one is the level of simple factual existence of these substances or things constituted by them. The existence of these things does not depend upon the fact of their

\footnotetext{
22 PraŚASTAPĀDA and ŚRĪDHĀRA 1895, 8. PraŚASTAPĀDA 2005, 33-34.

${ }^{23}$ PrAŚASTAPĀDA and ŚRĪDHĀRA 1895, 27. PrAŚASTAPĀDA 2005, 58-59.
} 
being known and even upon the existence of a knowing subject. In other words, earth, water and other substances were all the same even if atman would be excluded from Praśastapāda's list of dravyas. And it should be noted incidentally that the real subject of knowledge according both Vaiśeșika, Nyāya and Vedānta is àtman, while manas (in Vaiśeșika and Nyāya) or antahkēaraṇa (an internal organ in Vedānta) is nothing more than an instrument bringing the knowledge to ätman. In the scheme with ätman excluded we would have a situation where there were minds that collect and process information, but there were no consciousnesses that use the information collected by minds and make decisions on the goals to be sought. Similarly, $\bar{a} k \bar{a} s$ s $a$ would exist in such a world only virtually for there were no subject who can have an epistemological horizon actually.

The second level is the level of the existence of these entities as these are known by a subject. All the substances in this scheme can be known solely by their qualities and motion, and even motion is in fact a change in relations between a material thing (an integral set of atoms) and different points of space, through which the thing moves. An entity in itself is not accessible for the unenlightened mind, i.e. the mind that has not yet achieved nihśreyasa or the highest religious goal of the system. The mind of a common person can know an essence only through its manifestations in qualities and motion, i.e. indirectly, so the dravya as it is remains hidden from us.

Here the question arises as to whether a dravya really exists and is not a mental construction produced by tendency of human mind to see something constant behind the ever-changing flux of events and qualities even if there are really no constant thing equal to itself. But Vaiśeșikas' reply is that this constant entities are postulated in müla-śästra of the system, the Vaiśeșika-sūtras.

But if we examine closely the list of substances in Vaiśeșika we can see that not all of the items in the list denote strictly material substances epistemologically open to objective knowledge by external means of sense organs. In fact, only earth, water, fire and wind are the elements the knowledge of which is given by external organs. $\bar{A} k \bar{a} s$ s $a$ is a medium in which sound propagates, so, unlike the first four substances that are visible and tangible, $\bar{a} k \bar{a} s \dot{a} a$ is devoid of such qualities and it is this feature that makes this dravya peculiar in the list of Vaiśeșika substances. Being the medium for sound (PDS 1.5) ākāśa is unitary and indivisible, i.e. it does not have parts unlike all tangible entities. ${ }^{24}$ The characteristic feature of tangible substances according to Vaiśeșika-sütras and commentaries on it is that

\footnotetext{
${ }^{24}$ PrAŚASTAPĀDA and ŚRĪDHĀRA 1895, 58. PrAŚASTAPĀDA 2005, 96.
} 
qualities inherent to them can produce results different from their causes. Praśastapāda enumerates the characteristic qualities of $\bar{a} k \bar{a} s \dot{a} a$ as sound (for this substance is the only sound carrier), number, size, separateness, conjunction and disjunction (PDS 1.5: śabdasamkhyāparimānapṛthaktvasamyogavibhāga).

Time is treated in PDS as substance, though it is obviously not material. But time is perceived through its qualities. Time is defined in PDS as that that can be thought of in such notions as "earlier-later", "simultaneously-not simultaneously", "fast-long" etc., that are its conditioning signs (pratyayalinga; PDS 1.6). ${ }^{25}$ These notions are, according to Praśastapāda and Śrīdhāra, characteristic effects of the substance of time, for no other substance can be instrumental cause for them. Perception of time is due to difference of causes of other sensual perceptions. For example, when two different objects are perceived in one cognitive act, difference between them are cognized not only by their qualities but also by the temporal difference that separates even the objects that are absolutely the same in all other respects. So if epistemological horizon ( $\bar{a} k \overline{a s} a)$ as substance is a space where all possible objects of perception are placed being clearly discerned from each other, time as dravya is the aspect due to which the discernment of equal things in the same place in $\bar{a} k \bar{a} s \dot{a} a$ is possible. Or, to make it simpler, time is the substance, relating to which all other substances are defined as changing or immutable, or moving or resting etc.

It is also necessary to distinguish clearly the substances of epistemological horizon (and the carrier of the quality of sound) and of direction (diś) in physical space. From the first sight they may seem to be not exactly different, but if we examine accurately their qualities it will be obvious that the distinction between them is essential in the respect that $\bar{a} k \bar{a} s \dot{a} a$ is the space where objects (not things) are placed and recognized as existing and having their characteristic qualities, while diś or direction is the space where material things (being not necessarily objects) move relative to one another and can be perceived by sense organs.

Describing the substance of physical space or direction, Praśastapāda says that "direction is that from which ten ideas arise: east, south-east, south, south-west, west, north-west, north, north-east, below and above in relation to material substances, when some [other] material substance is taken as a reference point" (PDS 1.7: mürtadravyamavadhim krtvā mürteșveva dravyeșvetasmādidam pūrveṇa dakșinena paścimenottarena pūrvadakșinena

\footnotetext{
${ }^{25}$ PraŚASTAPĀDA and ŚRĪDHĀra 1895, 63. PrAŚASTAPĀDA 2005, 104.
} 
dakșināpareṇa aparottareṇa uttarapūrveṇa cādhastādupariș̣̂acceti daśa pratyayā yato bhavanti sā digiti). ${ }^{26}$ Keyword in this passage is avadhi "a term, limit; conclusion, termination" that can be translated here as "reference point". One substance or, more exactly, a material thing taken as a "zero point", becomes a basis of reference to any other material thing or group of things, which are allocated now in a coordinate scale generated by that basic thing. Direction as substance and size as quality are associated with each other, for, according to Śrīdhāra's commentary, immaterial object has neither the quality of size nor a limit or border and, since its size is limitless, such notions as east, west etc. are not applicable to it. This being so, ākāsa, ātman and manas as immaterial dravyas cannot be described in terms of direction and therefore have no place in physical space. At the same time, direction is described in terms of number (gana), size (parimāna), separateness (prthaktva), conjunction (samyoga) and disjunction (vibhāga), and these are the qualities characteristic for $\bar{a} k \bar{a} s a^{a}$ also. Assaying the socalled immaterial substances as described in PDS we may sum up their descriptions taking into consideration the qualities distinctive for them. So, gaṇa (number) marks such immaterial substances as ākāśa, diś, àtman, manas and time $(k \bar{a} l a)$. Number is discerned in sensual objects allocated in cognitive horizon, material things (vastu) placed in physical space; both material things and objects of cognition are determined in relation to time. Finally, there are many souls (jivva) each having attman (actual subject of cognition) and manas (basic instrument for cognition), so they too are defined as having number. Parimāna (size), like gana, characterizes ākāśa, diś, àtman, manas and kāla, and while the application of this quality to $\bar{a} k \bar{a} s$ a , time and direction is quite understandable, it may rouse a question as to how can parimāna be defined in such immaterial things as ätman and manas? The application of the idea of size to àtman is explained by Śrīdhāra with the support on Vaiśeșika-sūtras. When Kanāda says that ākāśa has infinitely large size, he adds "like ätman". This entails that, first, àtman has a size and, second, its size is as infinite as $\bar{a} k \bar{a} s a$, so the idea of size is explained as relevant to atman. The application of this idea to manas is obvious from PDS 1.9, for Praśastapāda openly says that manas has a material form since it is active (kriyāvattvān mürtatvam). ${ }^{27}$

Next, prthaktva characterizes also ākāśa, diś, àtman, manas and kāla, as postulated in PDS 2.7, where we read that separateness is the cause

\footnotetext{
${ }^{26}$ PraŚASTAPĀDA and ŚRĪDHĀra 1895, 66. PraŚASTAPĀDA 2005, 110.

${ }^{27}$ PraŚASTAPĀDA and ŚRĪDHĀra 1895, 89. PraŚASTAPĀDA 2005, 134.
} 
of the practice of dividing (prthaktvam apoddhāravyavahārakāranam) ${ }^{28}$ Śrīdhāra comments this passage saying that the practice of dividing (apoddhäravyavahära) is such a thought as "this is different from that". ${ }^{29}$ This quality is definable on all these substances just because every substance differs from any other one and objects of the sphere of some single substance differ from one another both qualitatively and numerically.

Then, conjunction (samyoga) is described as joining together of previously disjoint things (PDS 2.8: aprāptayoh prāptih samyogah) ${ }^{30}$ called forth by motion of one or both these things or by another conjunction, so this quality is defined on any pair of substances and on any pair of different items in the scope of a single substance. The opposite to this is vibhagga involving two substances or items of a substance. Conjunction is treated in PDS as the instrumental cause of the quality of being conjunct and is the reason (hetu) of substance, quality and motion as categories (PDS 2.8: samyogah samyuktapratyayanimittam, sa ca dravyagunakarmahetuh). ${ }^{31}$ But since atman and manas are characterized by these qualities, these dravyas are in the scope of motion and action as well as common material substances. This can be explained by the fact that every epistemological act presupposes a contact of sense organs (indriya) with a thing known and disjunction puts an end to this concrete epistemological act.

As Victoria Lyssenko reasonably observes, conjunction and disjunction are universal qualities inherent in any substance, so this can be specified only using the idea of putting something together or apart, and it follows that the qualities of conjunction and disjunction are fundamentally associated with the quality of motion or, better to say, motion itself manifests as disjoining or conjoining of an object with different points of space. ${ }^{32}$ And it may be added here that the relation of conjunction and disjunction appears, as has been noted above, between sense organ and its object as well and between the data of a sense organ and manas.

So, what is dravya according to Vaiśeșika philosophy? Taking into consideration all that is said above, we may conclude that dravya is not necessarily matter, though every matter is a kind of dravya. But the categorization of anything as dravya presupposes that this item can have (and, in fact, actually has) a quality or qualities that can be recognized as

\footnotetext{
${ }^{28}$ PrAŚASTAPĀDA and ŚRĪDHĀRA 1895, 138. PrAŚASTAPĀDA 2005, 191.

${ }^{29}$ PRAŚASTAPĀDA 2005, 191.

${ }^{30}$ PrAŚASTAPĀDA and Ś́RĪDHĀRA 1895, 139. PrAŚASTAPĀDA 2005, 194.

${ }^{31}$ PrAŚASTAPĀDA and ŚRĪDHĀRA 1895, 139. PrAŚASTAPĀDA 2005, 193.

${ }^{32}$ LYSSENKO 1986, 61.
} 
such by the human mind and discerned from similar qualities. Moreover, the fact that a quality is discerned may mean in some cases the discrimination between grades of the quality, when a person feel the difference, e.g., between warm and cold water. Dravya exists even without being known or discriminated from other dravyas or even from qualities or motions etc., and it does not depend on a knowing subject. Qualities are nothing more (and nothing less, of course) than external manifestations of dravya - but manifestations that show its material essence that is not necessarily recognized by a subject but necessarily determines its action and modes of its recognition.

Some dravyas may be divided into parts (we mean, of course, only material substances in the narrowest sense-earth, water, wind and fire), but is it true that all other dravyas-ätman, manas, ākāśa, diś, kāla - are indivisible? According to PDS 1.9, manas is unique in any body, ${ }^{33}$ so it may be concluded that in different bodies there are different manases, so, taking into account the atomistic nature of matter in Vaiśeșika, we may infer by analogy that manas is as much atomistic as any material substance. The main (and, possibly, the only) difference is that a person has many atoms of a material substance in his body but the atom of manas in him is always only one. The same is true, of course, concerning ätman. Atoms (paramānu) are minimal parts of a substance, i.e. parts that cannot be divided into smaller components and therefore have no internal structure. As any item of earth, water etc. is unitary but has the same qualities as any other atom of this substance, so any ätman has the same basic qualities as any other ätman and these are indiscernible relative to these fundamental qualities manifesting its essence. Since Vaiśeșika postulates the multiplicity of souls, every of which has its own ätman, it follows that there are many ātmans, unlike, for example, Vedānta where Attman is one, unique and universal being, whereas everything that a common person regards as real is in fact a manifestation of $m \bar{a} y \bar{a}$ - the creative power of Atman. We see therefore that a peculiar Vaiśeșika atomistic worldview extends not only to material substances but also to that which can be denominated mental. From this point if view every attman is an atom of that what can be called atmanic substance similar to any substance in the Vaiśeșika universe. The same is true concerning manas without which no knowledge would be possible and ätman and so-called material world would be totally disjoined.

But atomism, in spite of commonly accepted opinion, is not so much universal in this system, for in PDS Praśastapāda openly declares that such

${ }^{33}$ PraŚASTAPĀDA and ŚRĪDHĀRA 1895, 89. PraŚASTAPĀDA 2005, 134. 
dravyas as $\bar{a} k \bar{a} s$ a , direction and time are unitary, i.e. there are no "atoms" of these substances. These terms, according to PDS 1.5, are conventional (pāribhāṣik̄) , and Śrīdhāra explains that these names are called pāribhāsiki for the convention of using them is accepted without factual reason (the same is the case of proper names) while all other names are called determined (naimittika) for their use is accepted by a definite reason (nimitta-karana). ${ }^{34}$

Thus, dravya is understood in Vaiśeșika as a basis for qualities, some dravyas being atomistic i.e. divided into minute parts that cannot be divided further, and some dravyas like time, direction and epistemological horizon being indivisible. Irrespective of their atomistic or holistic nature every substance not only has qualities but also manifests itself through them. The category of motion (karman) cannot be applied to immaterial substances for they are all-pervasive ( $\bar{a} k \bar{a} s \dot{a}, k \bar{a} l a)$, have no place different from themselves (diś) or subtle (ätman).

$* * *$

The word dravya seldom occurs in Asanga's "Abhidharma-samuccaya". The first place where it is found is the part where Asanga discusses the aspects of groups (skandha), elements (dhätu) and bases of consciousness (áyatana). These aspects are substances (dravya), knowable objects (jñeya), forms (rüpāni), afflux of affects (äsrava), the appeared (utpanna), the past (atîta), conditions (pratyaya), the being or the way of being (katham, lit. "how" or "what"), quantity (kati, lit. "how many") and goal (kimartham, lit. "for what aim"). ${ }^{35}$ So, unlike Vaiśeșika authors, Asanga treats this term not as a category or the most general philosophical notion but as an aspect of three basic categories of Yogācāra philosophy. The level of generalization on which the notion of dravya functions is therefore much lower than in Vaiśeșika. But the treatment of the term in "Abhidharmasamuccaya" is quite interesting: dravya is described here as that what exists independently from words and propositions: "Substantial is [that part] of the sphere of sense organs, [that] does not depend on words [that describe or name it] and on anything [that is] different from it" (abhilāpanirapekșastadanyanirapekșaścendriyagocaro dravyamat). ${ }^{36}$

\footnotetext{
${ }^{34}$ PrAŚASTAPĀDA and ŚRĪDHĀRA 1895, 58-59. PRAŚASTAPĀDA 2005, 95-97.

${ }^{35}$ AsANGA 1950, 16.

${ }^{36}$ Ibidem.
} 
Asanga talks not about dravya or substance but about dravyamat or substantial. This moment is noteworthy in the respect that Asanga expresses here principal position of Buddhism, fixed in the term anatman. There are no dharmas that would have an essence independent from any knowledge or any subject of this knowledge. There is no eternal soul or subject that could die or evade death, since a person is a conglomeration of momentary elements (dharma) and the notion of "I" is nothing more than a mental construction. It can be assumed that dravya for a Buddhist mind would sound too "substantial", implying an essence other than dharmas and capable of being a support for them, what would fundamentally differ from basic Buddhist dogmas. So there is, in fact, no dravyas but just dramyamat, substantial in the sense of being independent of any concrete person's words or thoughts or of anything that is not this very thing or type of things. Substantial does not mean immutable or existent in itself or because of itself, and this is obvious from the word indriyagocara "the sphere of sense organs".

What indeed does it mean? In ASBh we read that this independence from words and verbal expressions in the sphere of sense organs means that any form or feeling or anything else that pertains to five groups (skandha) of dharmas is perceived and known in its specific being irrespective to the variety of names that can be given to this form or feeling etc. (abhilāpanirapekșa indriyagocarastadyathā rüpam vedanetyevamādikam nāmnācitrayitvā yasyārthasya grahanam bhavati) ${ }^{37}$. In fact, it is not correct to say that nothing can be asserted about these things. They can have names, we may express propositions about them, be these true or false, but these things depend only on themselves and any assertions on them do not change their nature.

The discussion here is about two fundamental types of dharmas dravyamat and prajñaptimat, the difference between them being that the first one does not depend on words while the second one does, for prajñaptimat is just a mere designation. But then Asanga says that all skandhas, dhātus and ayyatanas are prajñaptimat and are to be studied for overcoming the affective attachment to the notion of "I" as a designation. Thus the whole reality is in the same time substantial and designational. How can these assertions be reconciled with each other? Unfortunately, Sthiramati does not explain this passage, telling only about specifics of substantiality, so we can only make some assumptions corroborated more or less by the Buddhist texts. As Prof. E.P. Ostrovskaya and V.I. Rudoi remark, a dharma, being

\footnotetext{
${ }^{37}$ STHIRAMATI 1976, 20.
} 
as elementary and momentary state is substantial, but when it is regarded as an element of the description of the stream of consciousness it is defined as prajñaptimat or mere name.

We see here the first difference between Vaiśeșika and Yogācāra in relation to the treatment of the notion of substance. Vaiśeșika regards substances as a set of the most general classes of objects that have qualities and do not depend on each other, though may (and do) interact, for the world itself is the combination of substances, each of which is necessary and cannot be withdrawn without destruction of the world. In Yogācāra, on the other hand, dravya is just that that exists independently of words and other substances - the moment not so important in Vaiśeșika. Moreover, this notion in Yogācāra depends upon the point of view, for every skandha etc. may be treated as dravyamat (substantial) or prajñaptimat (conventional). So there is no essential difference between dravya and prajñapti, for this distinction is drawn depending on purposes of investigation into the nature of consciousness according to the principles of Yogācāra. This difference is, so to say, subject-depending (but it should be remembered that there is no real subject in Buddhism - but only conglomerations of momentary states of consciousness).

The second distinctive point concerns the place of the notion of dravya among (and in relation to) other categories of the systems regarded. In Vaiśeșika, as was shown above, substance is an entity that has qualities and performs action, thus manifesting itself. There is no substance without qualities and motion, though these may sometimes be concealed from human knowledge, and they may be in relation to each other, what becomes apparent in categories of generality (sāmānya), specificity (viśeșa) and inherence (samāvaya). Thus the basic category here is dravya. In Yogācāra the situation is quite different. Substantial is, first of all, a position of a subject and in fact no dharma can be regarded as essentially substantial and essentially conventional. So the peculiarity of Yogācāra thought consists here in quite a specific conceptual grid through which the world is understood in this system. Vaiśeșika discerns the term dravya from guna, karman etc., while in Yogācāra dravya lies in a row with the ideas of conventional relativity (samvrtti), absoluteness (paramārtha), materiality (rüpi) or immateriality (arüpi), visibility (sanidarśana) or invisibility (anidarśana), and the substantial is discerned here only from the conventional. ${ }^{38}$ The other distinctions intersect with the distinction of

\footnotetext{
${ }^{38}$ AsANGA 1950, 31.
} 
dravya/prajñapti, so a dharma may be both substantial and material or both substantial and invisible etc.

Other important Yogācāra text where dravya is met with is Vasubandhu's "Karma-siddhi-prakarana". In the first part of the work the author discusses the problem of sense perception and atomistic theory. According to that theory reality consists of minute and subtle particles (paramānu) that cannot be perceived and their existence can be only inferred. Vasubandhu discusses here some erroneous (from the Yogācāra point of view) doctrines in Buddhism, such as Sarvāstivāda, Vātsīpūtriya, Saṃmitiya etc., showing that these do not conform exactly to the basic principles of the teaching of the Buddha. In KSP dravya is translated usually as "entity", ${ }^{39}$ though the meaning of the term is more complicated than it may seem from the first sight. First of all, Vasubandhu raises the question as to whether "configuration" (samsthāna) is a special kind of atom, as a special aggregate of atoms are or some other single entity (dravya) pervading the aggregates. ${ }^{40}$ The core of the problem is the nature of manifest action of the body (kāyavijñapti): Vasubandhu's opponent assumes that kāyavijñapti is a "configuration which has arisen from a citta which has an object of consciousness referring to it". ${ }^{41}$ The importance of the question under discussion consists in that every conscious action creates karmic "fruit" that determines future destiny of the sentient being and some actions lead to further bondage in samsāra while other may help this being in attaining final liberation (nirvāna). Thus the topic under discussion is the idea of "manifest action" (vijñapti) pertaining to a person and creating karma. Commenting this passage, Stephen Anacker notes that Vaibhāșika has exact criteria for designating something dravya or real entity:

(1) its characteristics must be distinguished as special by at least one consciousness (Kośa I, ad 10d) (a characteristic of this sort is called a "svalakșana", "own-characteristic");

(2) it must not be susceptible to further division (Ibid., and Kośa VI, 4). True entities would thus to the Vaibhāșika be only the momentatoms of materiality and the momentary flashes of feelings, motivating dispositions, cognitions, and consciousness-perceptions. A body, a flame, and, for that matter, a consciousness-series, can thus not really be considered a dravya...

\footnotetext{
${ }^{39}$ ANACKER 1970, 101, 112, 135 etc.

${ }^{40}$ Ibidem 101.

${ }^{41}$ Ibidem 99.
} 
A dravya has a specific manner of being, or nature (its "own-being", svabhāva ) which is apprehended by one or another of the consciousnesses, or a combination of several, as an "own-characteristic". A change in characteristics is always a change in things: there are in fact no underlying entities which have characteristics - there is only whatever is presented to the consciousnesses themselves. ${ }^{42}$

Asanga's position, as can be seen, is quite different from that of Vaibhāșikas concerning the problem of the meaning of the term. In Vaibhāșika philosophy it was elementary and indivisible entity, constant in its essence, so it could exist only on the level of relative reality - the phenomenal world where everything changes and where one can speak about a "soul" that can "die" with the bodily death or "survive" it. In fact there can be no dravyas in such a philosophy, for a dravya being substratum of qualities and differing from them cannot be real in the conceptual grid of Buddhist philosophy. We may speak of substances when we stand on the position of common-sense truth, but taking the absolute point of view (paramārtha) we cannot already consider the world as substantial. In Yogācāra, on the other hand, dravya means not a reality or a level of it, but rather a mode of consideration of reality.

But the second aspect of the meaning of this word in Yogācāra is close to its meaning in Vaibhāșika or even Vaiśeșika in some relations. When Asañga speaks of inferior and highest (sottara, anuttara) dharmas, he tells that the investigation of the inferior dharmas is necessary for overcoming of affective attachment to Atman consisting of an inferior substance, and the investigation into highest dharmas is a means for elimination of attachment to Atman consisting of highest substance (ātmadravyahina, àtmadravyāgra) ${ }^{43}$ In this context the term apparently designates the substance that can be a "material" for atman. But since there is no atman in reality, the term dravya in this concrete context becomes empty.

The demonstration of emptiness of this term by Asanga goes also in another way. In the second part of AS he observes that

it is said that a mass of matter (rūpasamudāya) is composed of atoms. Here the atom (paramānu) should be understood as not having a physical body (niḩśarīra). The atom is determined (vyavasthāna)

\footnotetext{
42 ANACKER 2002, 123.

${ }^{43}$ Asanga 1950, 31.
} 
by means of ultimate analysis (paryantaprabhedatah) by the intellect (buddhyā), with a view to the dispelling (vibhāvana) of the idea of cluster (pindasamjna $\bar{a}$ ), and with a view to the penetration of the nonreality of the substance (dravyāparinispattipraveśa) of matter. ${ }^{44}$ Yatpunarūcyate paramāṇusamcitto rūpa samudāya iti tatra niḩsarīrạ paramānurveditavyah / buddhyā paryantaprabhedatastu paramāṇuvyavasthānam pị̣̣̂asamjñāvibhāghanatāmupādāya rūpe dravyāh parinișpattipraveśatāị copādāya. ${ }^{45}$

In this passage Asanga actually posits the thesis that matter (rüpa) cannot be substantial because it consists of atoms but no atom can be substantial, since it is not a material body. Of course, according to Asanga's thought (as it can be reconstructed here) if elements of a complex entity are not substantial the entity itself cannot be regarded as substance; there can be nothing new in complex entity that was not present in its elements.

For the better explication of the meaning of dravya in Buddhist texts let us examine the usage of the term in the most fundamental work of Vaibhāșika philosophy — the "Encyclopedia of Abhidharma" ("Abhidharmakośa") of Vasubandhu (5th c. A.D.) with a commentary on it "Abhidharmakośabhāṣya". In the systems of Theravāda and Vaibhāṣika dravya was treated as a fully real entity while Sautrāntika regarded it as an absolutely nominal notion having no reference in reality and designating mere absence of the affects that afflict common-person consciousness. ${ }^{46}$ But actually the Vaibhāșikas treated this notion in two ways complementary to each other: on the one hand, dharma was treated as a real entity which the stream of consciousness consists of, so from this point of view dharma was regarded as dravyamat; but on the other hand, as a unit of description of internal life of an individual it was regarded as existing only nominally, in the act of knowledge (prajñaptimat). ${ }^{47}$

In AK and AKB proper the word dravya may mean just "object" as in the first place where it occurs (AKB 1.6). This passage presents the theme of disjunction (visamyoga) from the affected dharmas as the cessation of their existence by the means of knowledge: pratisamkhyānirodho yo visamyogah prthak prthak. ${ }^{48}$ In AKB we read that the number of real objects of

\footnotetext{
${ }^{44}$ ASANGA 2001, 91.

${ }^{45}$ AsANGA 1950, 41-42.

${ }^{46}$ RUDOI 1998, 60.

${ }^{47}$ Ibidem 77.

${ }^{48}$ VASUBANDHU 1967, 3.
} 
disjunction is equal to the number of the objects of conjunction: $y \bar{a} v a n t i h i$ samyogadravyāṇi tāvanti visamyogadravyāni ${ }^{49}{ }^{4}$ and, as Prof. Ostrovskaya and Rudoi observe, "the objects of conjunction" are real psychosomatic states characterized by the afflux (sāsrava) of affects (kleśa). ${ }^{50}$ Thus dravya may mean in $\mathrm{AK}$ and $\mathrm{AKB}$ just an object, however not a common physical object but rather an object of affectual conditioning. The next instance where dravya has a peculiar meaning different from the above described one is the commentary on the last words of AK 1.10: "the tangible is of eleven types" (sprśyamekādaśätmakam). In AKB we read here that "the tangible by its nature is the eleven real entities: four great elements, mildness, hardness, heaviness, lightness, cold, hunger and thirst" (spraștavyamekādaśadravyasvabhāvam catvāri mahābhūtāni ślakṣnatvam karkaśatvam gurutvam laghutvam śîtam jighatsā pipāsā ceti). ${ }^{51} \mathrm{We}$ see here that dravya assumes somewhat different meaning, designating four gross material elements, qualities of material things composed of these elements and such somatic feelings as hunger, thirst and the feeling of cold that would hardly be regarded as substances from the commonsense point of view.

But, following along the text of $\mathrm{AK}$ and $\mathrm{AKB}$, we find that this meaning, though basic, does not exhaust all the possible meanings of the term. Already in AKB 1.15 we read that "these seven real entities acquire the name of dharmic base of consciousness and dharmic element class" (ityetāni sapta dravyāṇi dharmāyatanam dharmadhātuścetyākhyāyante). ${ }^{52}$ In this passage dravyāni "substances" designate groups of feeling (vedanā-skandha), concepts (samjñ̄a-skandha), forming factors (samskāra-skandha), the unmanifested (avijñapti) and three kinds of the undetermined (asamskrta). Vasubandhu does not enumerate the group of matter (rüpa-skandha) but it is quite possible that this is also dravya, a real entity but does not pertain to dharmic elements class and dharmic base of consciousness. Anyway, such a designation of these entities as "substances" or realia shows that according to Vasubandhu in the AK and AKB the term dravya meant something not only objective but also actual, apt to exert influence on other real things (and, possibly, to undergo influence from other realia). Indeed, the unmanifest (avijñapti) cannot be an object of direct cognition but it does effect on the life of a sentient being determining his karman and ensuring the

\footnotetext{
49 Ibidem 4.

${ }^{50}$ VASUBANDHU 1998, 260.

${ }^{51}$ VASUBANDHU 1967, 7.

${ }^{52}$ Ibidem 11.
} 
realisation of karmic effects during the time between the fulfilment of karmic deed and the manifestation of its karmic results. Thus dravya means here not only objects of direct cognition but also a real entity that can exert an effect on other entities irrespective of being or being not known. This real entity may be, of course, known only post factum, when the effect is exerted and its results are manifest. In this case we know that it exists not directly but just by its effects or secondary manifestations.

In the context of the problem under examination especially interesting is the passage AK 1.38: "Others are triple, one [class] is the real and the last three are momentary" (tridhā "nye dravyavānekah kṣanikah paścimāsthayah).$^{53}$ In AKB Vasubandhu (or whoever may be the author of the commentary) explains that "only indeterminate is ultimately real, for it is eternal" (asamskrtam hi sāratvād dravyam). ${ }^{54}$ V.I. Rudoi and E.P. Ostrovskaia (the translators of $\mathrm{AK}$ and $\mathrm{AKB}$ into Russian) explain that the term dravya in this context is used in the sense uncommon for Abhidharma - in the sense of an absolutely real entity beyond the law of cause and effect ruling over the empirical world. ${ }^{55}$ Usually the term paramartha-sat is used in such a meaning so the question may be posited as to the reasons for Vasubandhu to use that unusual word in this context. It may be only surmised that dravya might mean in AK and AKB the entity that is real par excellence, without being caused by anything else.

So the considerations that were set forth above lead us to some definite conclusions on the nature of differences between the interpretation of the notion of dravya in Vaiśeșika and Buddhist philosophy. In Vaiśeșika worldview reality is constituted by relations between substances that are stable and immutable in themselves. In this concern they are indeed "atomistic" in the sense that every "atom" is equal to itself, does not change and have a definite essence manifesting in its motion and modes of associating with other atoms of this type and of other types. But every "atom" has a set of qualities, through which it can be known. No essence for an unenlightened person - can be known directly, without knowledge of qualities. Nevertheless, dravyas exist independently of any knowing subject, and if we eliminate atman from this system other dravyas will exist and remain intact. The dravyas in Vaiśeșika consist of atoms (except ākāśa, kāla, diś and àtman), so their existence is constituted by the relation of atoms of

\footnotetext{
${ }^{53}$ Ibidem 26.

${ }^{54}$ Ibidem.

${ }^{55}$ VASUBANDHU 1998, 282.
} 
substances and of atom of a substance with a concrete place and moment of time. But both substances and their qualities are considered in Vaiśeșika as real, i.e. existing without knowing subject.

Yogācāra, on the opposite, regards substances as mere designations depending on knowing subject including his personal features, social position, previously accumulated karma and, of course, linguistic aspect of the subject. One and the same thing can be considered as dravyamat or prajñaptimat depending on a concrete situation, so the substantiality appears to be highly subjective. However, this subjectivity, in its turn, depends on the main goal of all religious practice of Buddhism - nirvāna, attaining of liberation from the wheel of birth and death. The choice of the position concerning any concrete thing - is it a substance or just a conceptual construction - must be determined therefore by the consideration of whether this position leads to final liberation that will permit a person to immediate knowledge of reality without means of sense organs and conceptualizing mind.

\section{Abbreviations}

AK: Vasubandhu. Abhidharmakośa.

AKB: Vasubandhu. Abhidharmakośa-bhāṣya.

AS: Asanga. Abhidharma-samuccaya.

ASBh: Sthiramati. Abhidharma-samuccaya-bhāṣya.

KSP: Vasubandhu. Karma-siddhi-prakarana.

PDS: Praśastapāda. Padārtha-dharma-saṃgraha.

TS: Umāsvāti. Tattvārtha-adhigama-sūtra.

\section{References}

ACHARYA, Diwakar 2014: On the Śaiva Concept of Innate Impurity (mala) and the Function of the Rite of Initiation. Journal of Indian Philosophy, 42, 9-25.

ANACKER, Stephen 1970: Vasubandhu: Three Aspects. A Study of a Buddhist Philosopher. $\mathrm{PhD}$ thesis. Wisconsin University.

ANACKer, Stephen 2002: Seven works of Vasubandhu, the Buddhist Psychological Doctor. Delhi, Motilal Banarsidass.

Asanga 1950: Abhidharma-samuccaya. Critically edited and studied by Pralhad Pradhan. Santiniketan: Visva-Bharati.

AsAnga 2001: Abhidharmacamuccaya: The Compendium of the Higher Teaching (Philosophy) by Asanga. Originally translated into French and annotated by Walpola Rahula. English version by Sara Boin-Webb. Fremont: Asian Humanities Press.

LoREnZEN, David 1991: Kāpālikas and Kālamukhas: Two Lost Śaivite Sects. Delhi, Motilal Banarsidass Publishers. 
LYSSENKO Victoria 1986: "Filosofiia prirody" v Indii: atomizm shkoly vaisheshika ["The Philosophy of Nature in India: Vaiśeșika Atomism]. Moscow: Nauka, GRVL.

Matilal, Bimal Krishna 1998: The Character of Logic in India. Albany, N.Y.: State University of New York Press.

MoniER-WiLliams, Monier 1899: A Sanskrit-English Dictionary: Etymologically and Philologically Arranged with Special Reference to Cognate Indo-European Languages. Oxford, The Clarendon Press.

PRAŚASTAPĀDA 2005: Sobranie kharakteristik kategorii («Padārtha-dharma-samgraha») [The Compendium of the Characteristics of Categories]. Transl. into Russian by V.G. Lyssenko. Moscow: Vostochnaia literatura.

PRAŚASTAPĀDA and ŚRĪDHĀRA 1895: The Bhāshya of Praśastapāda together with the Nyāyakandalī of Śrīdhāra. Ed. by V. Dvivedin. Benares: E.J. Lazarus \& Co.

RuDoI V.I. 1998: Vvedenie v buddiiskuiu filosofiiu [Introduction to Buddhist Philosophy]. In: Vasubandhu. Entsiklopediia Abhidharmy [The Encyclopedia of Abhidharma] (Abhidharmakośa). T. 1: Razdel I: Uchenie o klassakh elementov [Vol. 1, pt. I: The Teaching on the classes of elements]; Razdel II: Uchenie o faktorakh dominirovaniia $v$ psikhike [Pt. II: The Teaching on the Dominating Factors in Mind]. Ed. by E.P. Ostrovskaia, V.I. Rudoi. Moscow: Ladomir, 11-113.

SANDERSON, Alexis 1992: The Doctrine of Mālinīvijayottara. Ritual and speculation in Early Tantrism. Studies in Honour of André Padoux. Ed. by T. Goudriaan. Albany, N.Y.: State University of New York Press, 281-312.

SthiRAmati 1976: Abhidharmasamuccayabhāṣyam. Ed. by N. Tatia. Patna: Kāśīprasāda Jāyasavāla-Anuśîlana-Saṃsthā.

The Bhișmaparvan of Mahābhārata. Pune: Bhandarkar Oriental Research Institute, 1999. Electronic text entered by M. Tokunaga et al., revised by J. Smith et al. In: GRETIL Göttingen Register of Electronic Texts in Indian Languages [Site]. URL: http://gretil. sub.uni-goettingen.de/gretil/1_sanskr/2_epic/mbh/mbh_06_u.htm, 17.07.2017.

The Dronaparvan, being the Seventh Book of the Mahābhārata, the Great Epic of India. Ed. by S.K. De. Poona: Bhandarkar Oriental Research Institute, 1958.

The Śalyaparvan, being the Ninth Book of the Mahābhārata, the Great Epic of India. Ed. by R.N. Dandekar. Poona: Bhandarkar Oriental Research Institute, 1961.

VAsubandHu 1967: Abhidharmakośabhāsya of Vasubandhu. Ed. by P. Pradhan. Patna: K.P. Jayaswal Research Institute.

VASUBANDHU 1998: Entsiklopediia Abhidharmy [The Encyclopedia of Abhidharma] (Abhidharmakośa). T. 1: Razdel I: Uchenie o klassakh elementov [Vol. 1, pt. I: The Teaching on the classes of elements]; Razdel II: Uchenie o faktorakh dominirovaniia $v$ psikhike [Pt. II: The Teaching on the Dominating Factors in Mind]. Ed. by E.P. Ostrovskaia, V.I. Rudoi. Moscow: Ladomir.

ZHeleZnova N.A. 2012: Digāmbarskaia filosofia ot Umāsvāti do Nemichandry: istorikofilosofskie ocherki [Digāmbara Philosophy from Umāsvāti to Nemicandra: historicophilosophical essays]. Moscow: Vostochnaia literatura. 